\title{
Evaluation of nutraceutical properties of Leucaena leucocephala leaf pellets fed to goat kids infected with Haemonchus contortus
}

Carine Marie-Magdeleine ${ }^{1}$, Steve Ceriac ${ }^{1}$, Dingamgoto Jesse Barde ${ }^{1}$, Nathalie Minatchy ${ }^{1}$, Fred Periacarpin², Frederic Pommier ${ }^{2}$, Brigitte Calif ${ }^{1}$, Lucien Philibert ${ }^{1}$, Jean-Christophe Bambou ${ }^{1}$ and Harry Archimède ${ }^{1 *}$

\begin{abstract}
Background: Leucaena leucocephala, as a shrub legume rich in condensed tannins, is a candidate for the integrated control of gastrointestinal parasitic pathogen nematodes. Here, we investigated the anthelmintic potential of the nutraceutical L. leucocephala, transformed into pellets, against Haemonchus contortus.

Results: Creole goat kids were fed an iso-nitrogenous diet of Dichantium hay with alfalfa pellets or Leucaena pellets or an alfalfa-leucaena mixture in varying ratios. The artificial infection of kids with $\mathrm{H}$. contortus led to infection levels comparable to those observed in the farm environment on the basis of egg excretion. The anthelmintic activity of Leucaena, compared to alfalfa, was demonstrated by its potential to reduce egg excretions (1524 vs. 3651 eggs/g) and the larval development of excreted eggs (3.5 vs. 24\%). This anthelmintic potential was reported when the ratio of Leucaena incorporation in the diet was high (50\% DM intake). The voluntary dry matter intake (79.3 vs. $77.0 \mathrm{~g}$ Large Weigth ${ }^{0.75}$ ), the total tract dry matter digestion ( 0.585 vs. 0.620$)$, and the growth $(57.1 \mathrm{vs} .71 .3 \mathrm{~g} / \mathrm{d}$ ) of kids fed Leucaena compared to alfalfa indicate that Leucaena has a high feed value. The Leucaena, even at the highest intakes in the diets, has not shown any signs of poisoning in kids.
\end{abstract}

Conclusions: Leucaena fulfilled the conditions to be a good nutraceutical, and pelleting is a good method for its use.

Keywords: goat kid, Leucaena leucocephala, nutraceutical, gastrointestinal parasite, feed, anthelmintic, growth

\section{Background}

Gastrointestinal parasitic nematodes (GINs) in small ruminants are a major constraint on animal health and well-being and the economic profitability of farms, and the magnitude of the problem is accentuated in the humid tropics [1]. Today, the main method used to control GINs is still the use of synthetic chemical

\footnotetext{
* Correspondence: harry.archimede@inra.fr

'INRAE, UR143, Unité de Recherches Zootechniques, French West Indies, 97170 Petit-Bourg, Guadeloupe

Full list of author information is available at the end of the article
}

anthelmintics; however, the resistance of parasites to chemical molecules weakens this control strategy [2-4]. There is thus an urgent need to develop integrated control methods [5, 6] combining the genetic selection of resistant and resilient animals, pasture management, adapted nutrition, and anthelmintic plants. As part of this integrated control, research into the use of some nutraceutical plants as feed $[7,8]$ rich in condensed tannins (CTs) and protein roughage is ongoing. The CTs and protein overnutrition have direct and indirect effects on the development and effects of GINs. The beneficial

C C The Author(s). 2020 Open Access This article is licensed under a Creative Commons Attribution 4.0 International License, which permits use, sharing, adaptation, distribution and reproduction in any medium or format, as long as you give appropriate credit to the original author(s) and the source, provide a link to the Creative Commons licence, and indicate if changes were made. The images or other third party material in this article are included in the article's Creative Commons licence, unless indicated otherwise in a credit line to the material. If material is not included in the article's Creative Commons licence and your intended use is not permitted by statutory regulation or exceeds the permitted use, you will need to obtain permission directly from the copyright holder. To view a copy of this licence, visit http://creativecommons.org/licenses/by/4.0/ The Creative Commons Public Domain Dedication waiver (http://creativecommons.org/publicdomain/zero/1.0/) applies to the data made available in this article, unless otherwise stated in a credit line to the data. 
effect of CTs against worms can be offset by their depressive effect on the feed value of the forage, as demonstrated by a reduction in intake and digestion. It is therefore advisable to evaluate the nutraceutical according to at least these two criteria: feed and anthelmintic value. The dosage (amount and rate of intake) of the nutraceutical is also an open question. The value of the nutraceutical should be assessed according to its efficacy against GINs that have already acquired resistance to synthetic chemical anthelmintics and its potential to generate new resistance in GINs. Finally, technological innovations, such as the form of presentation of the nutraceutical, could allow the use of a nutraceutical more appropriate to the scale of the farm' [8-10]. In small farmed ruminants, goats are the most sensitive species to GINs. Within this species, kids are the most sensitive animals. Consequently, kids are used as model animals to study this pathology. The main objective of this study was to evaluate the feed and anthelmintic potential of the nutraceutical Leucaena leucocephala, a shrub legume rich in condensed tannins, transformed into pellets. We evaluated the effect of several doses of pellets in the diet and the efficiency of L. leucocephala against Haemonchus contortus. Some preliminary results of this study were reported at the 10th International Symposium on the Nutrition of Herbivores [11].

\section{Results}

Results beyond 29 post-infection only concern 4 animals per lot due to slaughter.

The intake and total tract digestion values are reported in Table 1 . Whatever the mode of expression $\left(\mathrm{g} / \mathrm{d}, \mathrm{g} / \mathrm{kg} \mathrm{LW}^{0.75}, \mathrm{~g} / \mathrm{kg} \mathrm{LW}\right)$, the total dry matter (DM) intakes were similar for non-infected kids fed supplements composed of $100 \%$ alfalfa or Leucaena.
Comparison of these last diets revealed that the DM intake was lower or tended to be lower for noninfected kids than for infected kids. The DM total tract digestion tended to be lower $(\mathrm{P}=0.07)$ in noninfected kids fed supplements composed of $100 \%$ Leucaena than those fed with $100 \%$ alfalfa. No difference in the DM total tract digestion was reported for noninfected kids and infected kids fed diets with supplements composed of $100 \%$ alfalfa. However, a lower DM total tract digestion was reported for infected kids than non-infected kids and kids fed diets with supplements composed of 100\% Leucaena. The digestible crude protein (CP) intakes were similar for noninfected kids fed supplements composed of $100 \%$ alfalfa or Leucaena.

No significant effect of parasitism on total tract digestion (ttd) of CP, neutral detergent fibre (NDF) or acid detergent fibre (ADF) was found for diets supplemented with $100 \%$ alfalfa (Table 2). The CPttd of diets supplement with $100 \%$ Leucaena was lower for infected kids than for non-infected kids, whereas no difference was observed for NDF and ADF. The average daily gain (ADG) values are reported in Table 3. Overall, the ADG was lower with the Leucaena diet than the alfalfa and alfalfa-Leucaena diets (Table 3). No difference was recorded between these last two diets. Within the same diet, no difference in growth was found between infected and non-infected kids.

Overall, the feed indices tended to be higher for the Leucaena diet than the alfalfa and alfalfa-Leucaena diets; however, the difference was only significant for the uninfected kids fed Leucaena. Within the same diet, the

Table 1 Intake of uninfected (U) or infected (I, with H. contortus) Creole kids eating: Dichanthium spp. hay + alfalfa pellet (A); Dichanthium spp. hay + L. leucocephala pellet $(\mathrm{L})$; Dichanthium spp. hay $+(25 \%$ L. leucocephala pellet $+75 \%$ alfalfa pellet; $25 \mathrm{~L})$; Dichanthium spp. hay $+(50 \%$ L. leucocephala pellet $+50 \%$ alfalfa pellet; $50 \mathrm{~L})$

\begin{tabular}{|c|c|c|c|c|c|c|c|c|c|c|}
\hline \multirow[b]{2}{*}{ Item } & \multicolumn{7}{|c|}{ Treatment } & \multicolumn{3}{|c|}{$P$-value } \\
\hline & $U-A$ & $\mid-25 L$ & $1-50 L$ & I-A & $U-L$ & I-L & SE & Treatment & Diet & Infection \\
\hline Dry Matter g/d /Live Weight ${ }^{0.75}$ & 77.0ab & $82.0 \mathrm{a}$ & $78.9 a$ & $73.6 b$ & $79.3 a$ & $70.8 b$ & 2.27 & 0.0024 & 0.0037 & 0.0289 \\
\hline Dry Matter g/Live Weight & $41.5 \mathrm{ab}$ & $44.0 \mathrm{a}$ & $42.9 b$ & $39.9 a$ & $42.4 \mathrm{a}$ & $39.2 b$ & 1.18 & 0.0370 & 0.0286 & 0.1269 \\
\hline Digestible Dry Matter/Live Weight ${ }^{0.75}$ & $48.2 \mathrm{a}$ & $51.7 \mathrm{a}$ & $49.5 a$ & $45.8 \mathrm{a}$ & $46.8 \mathrm{a}$ & $39.6 b$ & 1.99 & $<0.0001$ & 0.009 & 0.0440 \\
\hline Dry Matter, g/d & $497.4 b$ & $535.0 b$ & $466.5 a$ & $497.2 \mathrm{ab}$ & $521.8 b$ & $414.7 c$ & 25.05 & 0.0079 & 0.0119 & 0.0189 \\
\hline Organic Matter, g/d & $455.1 b$ & $489.1 b$ & $425.5 a$ & $454.5 \mathrm{ab}$ & $481.0 b$ & $381.8 \mathrm{c}$ & 22.89 & 0.0098 & 0.0134 & 0.0158 \\
\hline Crude Protein, g/d & $83.7 c$ & $108.2 b$ & $84.1 \mathrm{C}$ & $90.8 \mathrm{a}$ & $102.9 b$ & $86.1 \mathrm{ac}$ & 5.34 & 0.0078 & 0.0012 & 0.1690 \\
\hline Digestible Crude Protein g/Live Weight ${ }^{0.75}$ & $8.7 \mathrm{a}$ & $9.9 a$ & $8.4 b$ & $8.0 \mathrm{a}$ & $7.5 a$ & $6.6 c$ & 0.56 & $<0.0001$ & 0.0015 & 0.3743 \\
\hline Neutral Detergent Fibre, g/d & $298.7 a$ & $292.9 a$ & 295.0a & $269.4 a$ & $283.9 a$ & $217.5 b$ & 13.76 & $<0.0001$ & 0.0010 & 0.0039 \\
\hline Acid Detergent Fibre, g/d & $173.4 \mathrm{a}$ & 157.0a & 168.7a & $159.6 a$ & $144.9 a$ & $110.9 b$ & 7.68 & $<0.0001$ & $<0.0001$ & 0.0097 \\
\hline Consumption index, g feed/g Daily Growth & $7.0 \mathrm{~b}$ & $6.3 \mathrm{ab}$ & $6.9 a$ & $6.5 a b$ & $9.2 \mathrm{C}$ & $7.2 \mathrm{~b}$ & 0.50 & 0.0152 & 0.0396 & 0.0366 \\
\hline
\end{tabular}

a, b, c: Means lacking a common letter differ $(p<0.05)$ 
Table 2 Total tract digestibility of uninfected $(U)$ or infected (I, with $H$. contortus) Creole kids eating: Dichanthium spp. hay + alfalfa pellet (A); Dichanthium spp. hay + L. leucocephala pellet (L); Dichanthium spp. hay + $(25 \%$ L. leucocephala pellet $+75 \%$ alfalfa pellet; 25 L); Dichanthium spp. hay $+(50 \%$ L. leucocephala pellet $+50 \%$ alfalfa pellet; $50 \mathrm{~L})$

\begin{tabular}{|c|c|c|c|c|c|c|c|c|c|c|}
\hline & & & & Treatment & & & & & $P$-value & \\
\hline Item & U-A & $\mathrm{I}-25 \mathrm{~L}$ & $\mathrm{I}-50 \mathrm{~L}$ & I-A & $\mathrm{U}-\mathrm{L}$ & I-L & SE & Treatment & Diet & Infection \\
\hline Dry Matter & $0.620 \mathrm{a}$ & $0.625 a$ & $0.624 a$ & $0.617 a$ & $0.585 \mathrm{ac}$ & $0.548 b$ & 0.0143 & $<0.0001$ & 0.0016 & 0.2363 \\
\hline Organic Matter & $0.585 a$ & $0.590 \mathrm{a}$ & $0.586 a$ & $0.587 a$ & $0.550 \mathrm{c}$ & $0.509 b$ & 0.0157 & $<0.0001$ & 0.0028 & 0.2143 \\
\hline Crude Protein & $0.648 a$ & $0.651 a$ & $0.649 a$ & $0.675 a$ & $0.569 a$ & $0.516 b$ & 0.0166 & $<0.0001$ & $<0.0001$ & 0.5166 \\
\hline Neutral Detergent Fibre & $0.640 \mathrm{a}$ & $0.595 a$ & $0.631 a$ & $0.605 a$ & $0.558 b$ & $0.494 b$ & 0.0231 & $<0.0001$ & $<0.0001$ & 0.0565 \\
\hline Acid Detergent Fibre & $0.614 a$ & $0.520 \mathrm{a}$ & $0.592 \mathrm{ab}$ & $0.582 b$ & $0.442 c$ & $0.352 c$ & 0.0333 & 0.01010 & $<0.0001$ & 0.1029 \\
\hline Average Daily Gain (ADG) (g/d) & 71.3a & $75.9 a$ & $90.0 \mathrm{~b}$ & $74.6 a$ & $57.1 \mathrm{C}$ & $59.9 c$ & 4.49 & 0.0669 & 0.0002 & 0.5147 \\
\hline
\end{tabular}

$\mathrm{a}, \mathrm{b}, \mathrm{c}$ : Means lacking a common letter differ $(p<0.05)$

differences were significant only with Leucaena, where values were significantly higher with non-infected kids.

The partition of nitrogen flows is presented in Table 3. Overall, nitrogen intakes were lower with Leucaena than with the other diets. When nitrogen intake is taken into account as a covariate in the statistical model, faecal and urinary nitrogen excretion is similar to that shown in Table 3. The faecal nitrogen excretions were lower with the alfalfa diets compared to the Leucaena diet. No difference was observed between infected and non-infected kids fed the same diet. When nitrogen intake is taken into account as a covariate in the statistical model, urinary excretion is lower with the Leucaena diet than the alfalfa diet. Leucaena diet leads to lower urinary nitrogen excretions than the alfalfa-Leucaena diet. No difference in urinary excretion was observed between infected and non-infected kids fed the same diet. Only noninfected kids fed the Leucaena diet had significantly higher values of retained nitrogen compared to the other treatments. The predicted ADG values were higher than those measured and the tendencies observed were similar to those reported for retained nitrogen.

The weekly evaluations of eosinophils are summarised in Fig. 1. There was no difference between the two control diets whichever time point was considered. The eosinophil counts post infections were higher with infected kids eating Alfalfa (IA) than with uninfected kids eating Alfalfa (UA); however, differences were only significant in weeks 2 and 5 . The eosinophil counts post infection were higher with infected kids eating $L$. leucocephala (IL) than with uninfected kids eating $L$. leucocephala (UL). No significant difference was observed between infected kids regardless of their diet.

The weekly evaluations of blood packed cell volume (PCV) are summarised in Fig. 2. The PCVs did not vary with time for the two control diets. Furthermore, there was no difference between the two control diets whichever time point is considered. The PCV values post infection were lower with IA than with UA; however, the differences were only significant in weeks 2,3 , and 4 . No significant difference was observed between infected kids regardless of their diet, except for the comparison of IA vs. IL, for which the values were lower with Leucaena in weeks 3,5 , and 6 post infection.

The weekly evaluation of faecal egg count (FEC) are summarised in Fig. 3. As expected, the FEC was zero for the uninfected kids. The FECs varied with time, as expected. The FEC values post infection were significantly

Table 3 Partition of nitrogen intake and growth of uninfected (U) or infected (I, with H. contortus) Creole kids eating: Dichanthium spp. hay + alfalfa pellet (A); Dichanthium spp. hay + L. leucocephala pellet (L); Dichanthium spp. hay + (25\% L. leucocephala pellet + $75 \%$ alfalfa pellet; 25 L); Dichanthium spp. hay $+(50 \%$ L. leucocephala pellet $+50 \%$ alfalfa pellet; $50 \mathrm{~L})$

\begin{tabular}{|c|c|c|c|c|c|c|c|c|c|c|}
\hline & & & & Treatme & & & & & $P$-value & \\
\hline Items & U-A & $\mid-25 L$ & $\mathrm{I}-50 \mathrm{~L}$ & I-A & $\mathrm{U}-\mathrm{L}$ & $\mathrm{I}-\mathrm{L}$ & SE & Treatment & Diet & Infection \\
\hline $\mathrm{N}$ intake $\mathrm{g} / \mathrm{d}$ & $13.4 \mathrm{a}$ & $17.0 \mathrm{a}$ & $15.0 \mathrm{a}$ & $13.5 \mathrm{a}$ & $16.5 a$ & $12.7 b$ & 0.88 & 0.1217 & 0.0012 & 0.1690 \\
\hline $\mathrm{N}$ in faeces $\mathrm{g} / \mathrm{d}$ & $4.5 \mathrm{c}$ & $6.0 c$ & $5.1 \mathrm{ab}$ & $4.3 a$ & $7.1 \mathrm{~b}$ & $6.3 a b$ & 0.33 & 0.0015 & $<0.0001$ & 0.3943 \\
\hline$N$ in urine $\mathrm{g} / \mathrm{d}$ & $5.2 \mathrm{c}$ & $7.1 \mathrm{c}$ & $6.3 a$ & $5.9 a$ & $3.2 b$ & $4.7 \mathrm{~b}$ & 0.44 & $<0.0001$ & 0.0013 & 0.0174 \\
\hline $\mathrm{N}$ retained & $3.8 \mathrm{a}$ & $3.9 \mathrm{a}$ & $3.5 \mathrm{a}$ & $3.6 a$ & $6.2 b$ & $1.8 \mathrm{a}$ & 0.79 & 0.0669 & 0.7324 & 0.0234 \\
\hline Average Daily Gain predicted (g/d) & $114.9 a$ & $110.7 a$ & $106.5 a$ & 109.3a & $189.3 c$ & $54.7 b$ & 24.83 & 0.0669 & 0.7112 & 0.0114 \\
\hline Average Daily Gain (ADG) (g/d) & $58.0 \mathrm{a}$ & $90.0 \mathrm{~b}$ & $74.5 b$ & $66.0 \mathrm{a}$ & $57.1 \mathrm{C}$ & $59.9 c$ & 4.49 & 0.0669 & 0.0017 & 0.5498 \\
\hline
\end{tabular}

$\mathrm{a}, \mathrm{b}, \mathrm{c}$ : Means lacking a common letter differ $(p<0.05)$ 


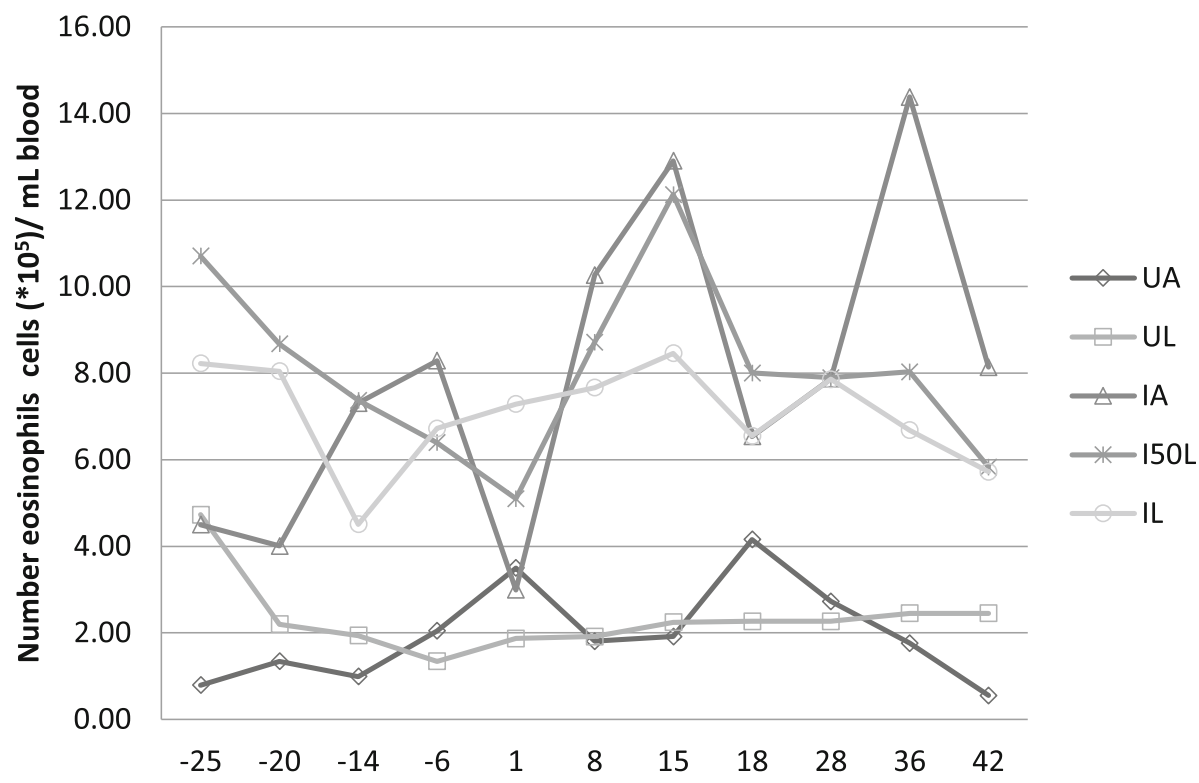

Fig. 1 Evaluation of eosinophils from uninfected Creole kids and infected Creole kids eating various diets: kids infected with Haemonchus contortus and fed hay $+300 \mathrm{~g}(62 \%$ alfalfa $+38 \%$ soybean) ( $\Delta)$; kids infected with Haemonchus contortus and fed hay $+300 \mathrm{~g}(47 \% \mathrm{alfalfa}+25 \%$ Leucaena $+28 \%$ soybean) $(x)$; kids infected with Haemonchus contortus and fed hay $+300 \mathrm{~g}(30 \%$ alfalfa $+50 \%$ Leucaena $+20 \%$ soybean) $(*)$ : kids infected Haemonchus contortus and fed hay $+300 \mathrm{~g}$ Leucaena ( $(0)$; uninfected kids fed hay $+300 \mathrm{~g}(62 \%$ alfalfa $+38 \%$ soybean) ( () ; uninfected kids fed hay $+300 \mathrm{~g}$ Leucaena ( $($ ). Results beyond 29 post-infection only concern 4 animals per lot due to slaughter

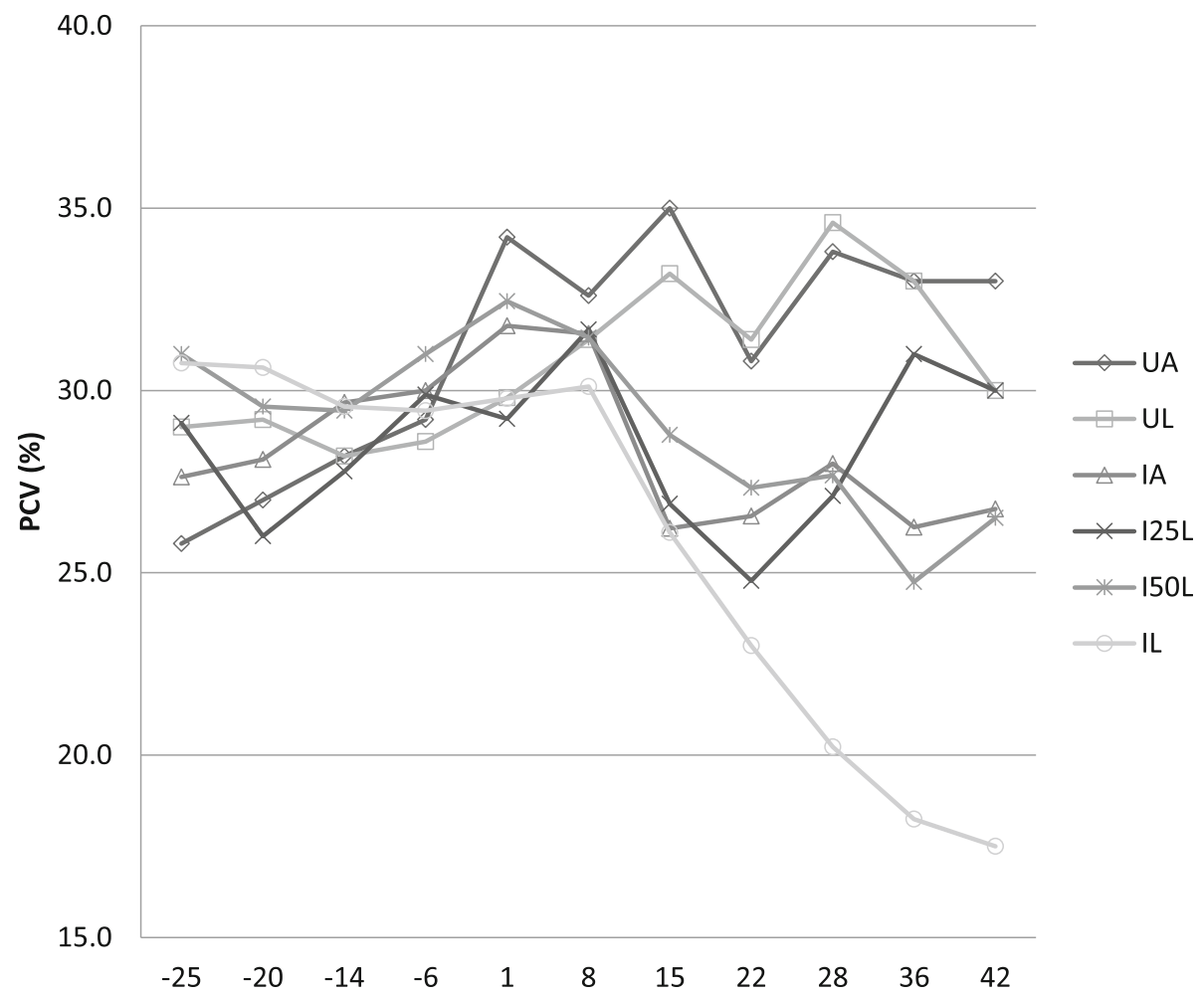

Fig. 2 Evaluation of PCV in uninfected Creole kids and infected Creole eating various diets; kids infected with Haemonchus contortus and fed hay $+300 \mathrm{~g}(62 \%$ alfalfa $+38 \%$ soybean) ( $\Delta)$; kids infected with Haemonchus contortus and fed hay $+300 \mathrm{~g}(47 \%$ alfalfa $+25 \%$ Leucaena $+28 \%$ soybean) (x); kids infected with Haemonchus contortus and fed hay $+300 \mathrm{~g}$ (30\% alfalfa $+50 \%$ Leucaena $+20 \%$ soybean) (*): kids infected Haemonchus contortus and fed hay $+300 \mathrm{~g}$ Leucaena (o); uninfected kids fed hay $+300 \mathrm{~g}(62 \%$ alfalfa $+38 \%$ soybean) ( () ); uninfected kids fed hay $+300 \mathrm{~g}$ Leucaena (). Results beyond 29 post-infection only concern 4 animals per lot due to slaughter 


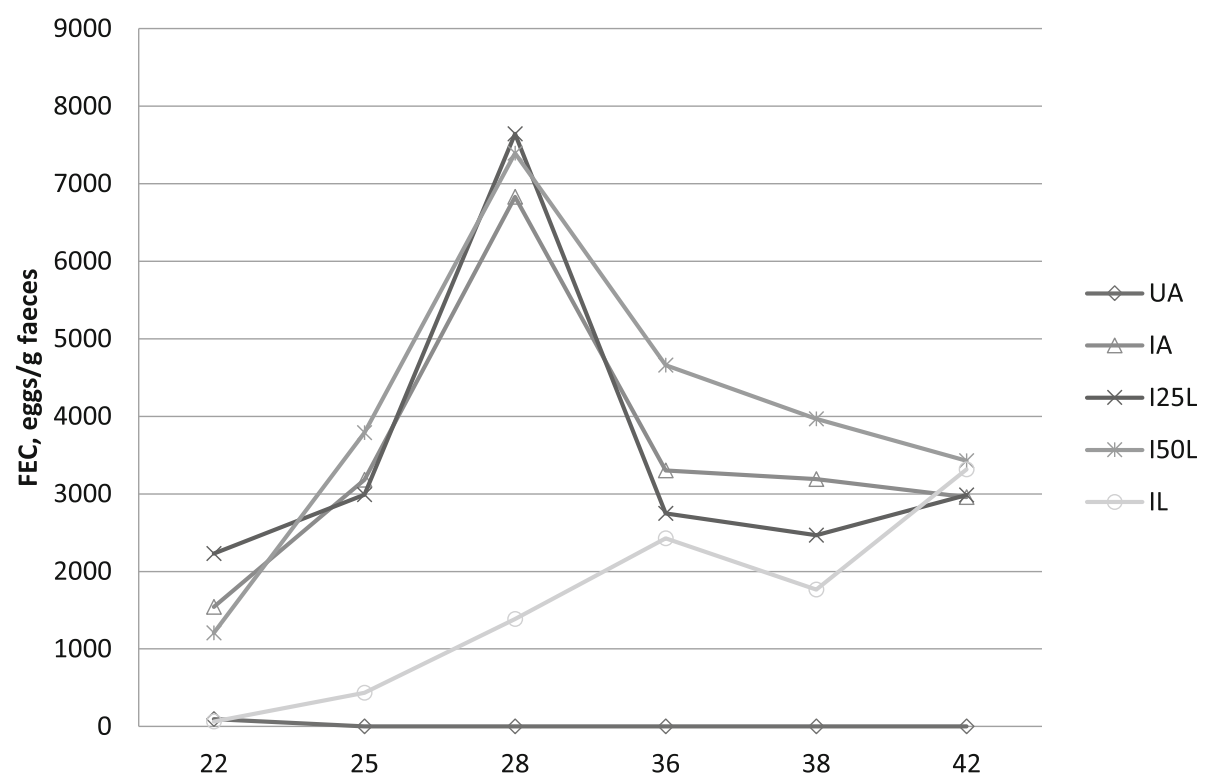

Fig. 3 Evaluation of FECs from uninfected Creole kids and infected Creole kids eating various diets: kids infected with Haemonchus contortus and fed hay $+300 \mathrm{~g}(62 \%$ alfalfa $+38 \%$ soybean) $(\Delta)$; kids infected with Haemonchus contortus and fed hay $+300 \mathrm{~g}(47 \%$ alfalfa $+25 \%$ Leucaena $+28 \%$ soybean) (x); kids infected with Haemonchus contortus and fed hay $+300 \mathrm{~g}(30 \%$ alfalfa $+50 \%$ Leucaena $+20 \%$ soybean) (*): kids infected Haemonchus contortus and fed hay $+300 \mathrm{~g}$ Leucaena (o); uninfected kids fed hay $+300 \mathrm{~g}(62 \%$ alfalfa $+38 \%$ soybean) ( $)$ ); uninfected kids fed hay $+300 \mathrm{~g}$ Leucaena ( $\square$ ). Results beyond 29 post-infection only concern 4 animals per lot due to slaughter

lower with IL than with IA from weeks 3 to 6 . By week 7, the difference became insignificant for IL vs. IA.

No effect of diet was found on the total number of male and female worms (Table 4). The number of immature male and female worms was higher with Leucaena diets. The sex ratio of mature male/ mature female worms was lower with Alfalfa diet. The number of eggs in utero was lower with the Leucaena diets than with the other diets. The same tendency was observed for worm lengths, with the lowest values reported for Leucaena diets. Faecal eggs development decreased with the amount of leucaena.

\section{Discussion}

The chemical composition of Leucaena was agreement with previous results reported [12]. The intake and

Table 4 Faecal eggs development and worm characteristics in the abomasum of uninfected (U) or infected (I, with $H$. contortus) Creole kids eating: Dichanthium spp. hay + alfalfa pellet (A); Dichanthium spp. hay + L. leucocephala pellet (L); Dichanthium spp. hay + (25\% L. leucocephala pellet $+75 \%$ alfalfa pellet; 25 L); Dichanthium spp. hay $+(50 \%$ L. leucocephala pellet $+50 \%$ alfalfa pellet; $50 \mathrm{~L})$

\begin{tabular}{|c|c|c|c|c|c|c|c|}
\hline & & & Treatment & & & $P$-value & \\
\hline Item & I-A & $1-25 \mathrm{~L}$ & $\mathrm{I}-50 \mathrm{~L}$ & $\mathrm{I}-\mathrm{L}$ & SE & Treatment & Leucaena \\
\hline Total worms & 773.8 & 982.0 & 705.8 & 897.6 & 187.44 & 0.750 & 0.506 \\
\hline Male (\%) & 43.3 & 51.3 & 48.5 & 46.2 & 2.32 & 0.1693 & 0.1252 \\
\hline Female (\%) & 56.7 & 55.8 & 51.3 & 53.8 & 2.24 & 0.4326 & 0.3324 \\
\hline Immature worms (\%) & $1.7 \mathrm{a}$ & $2.4 \mathrm{a}$ & $3.0 \mathrm{a}$ & $9.7 b$ & 2.20 & 0.0265 & 0.0111 \\
\hline Immature male worms (\%) & $0.9 a$ & $1.6 a$ & $1.0 \mathrm{a}$ & $5.6 b$ & 1.21 & 0.0140 & 0.0080 \\
\hline Immature female worms (\%) & $2.2 \mathrm{a}$ & $2.8 \mathrm{a}$ & $4.4 \mathrm{a}$ & $13.0 \mathrm{~b}$ & 3.03 & 0.0315 & 0.0130 \\
\hline Sex ratio mature male female (\%) & 79.4 & 93.7 & 98.1 & 94.0 & 6.34 & 0.0485 & 0.0770 \\
\hline Female worm length, $\mathrm{cm}$ & $1.929 a b$ & $1.951 \mathrm{a}$ & $1.921 \mathrm{ab}$ & $1.838 \mathrm{ab}$ & 0.0444 & 0.0128 & 0.0261 \\
\hline Eggs in utero & 209.3ab & $242.1 \mathrm{a}$ & $247.3 a$ & $102.2 \mathrm{bc}$ & 30.76 & 0.0010 & 0.0032 \\
\hline Faecal eggs development (\%) & $24.0 \mathrm{a}$ & $14.0 \mathrm{~b}$ & $12.7 \mathrm{~b}$ & $3.5 c$ & 3.50 & 0.0009 & $<0.0001$ \\
\hline
\end{tabular}

a, b, c: Means lacking a common letter differ $(p<0.05)$ 
digestibility decreases observed for sick animals compared to healthy animals. This is a relatively frequent, though unsystematic, as reported in the literature [1315]. A large reduction in intake 3 weeks post infection is reported [14], which is quite comparable to our observations. However, variable impacts (lag time post infection and the magnitude and duration of intake reduction) of gastrointestinal parasitism are observed, probably related to the animal's history, the infecting strain, the extent of the infection, and the feed characteristics [14]. The depressive effect of gastrointestinal parasites on total digestibility has also been reported in a literature review [15]. A meta-analysis reported that for a one-unit increase in log-transformed FEC, the DM intake and organic matter digestibility decreased by $8.68 \mathrm{~g} / \mathrm{kg}$ $\mathrm{LW}^{0.75}$ and $1.21 \%$ respectively, for sheep and goats [15].

The reduction in the PCV from 1 week after infection is a classical result that elicits the haematophagous activity of $H$. contortus [16]. A meta-analysis reported that for a one-unit increase in log-transformed FEC, PCV decreased by $62.8 \%$ and $23.4 \%$ for sheep and goats, respectively [15]. Thus, gastrointestinal parasitism increases the nutrient requirement (energy, proteins, and minerals) to compensate for some endogenous losses (blood, sloughed cells, etc.) [17]. Feeds rich in protein increase the resilience of animals, counterbalancing the haematophagous action of $H$. contortus, as observed with the alfalfa and mixed alfalfa-Leucaena diets. The lowest PCVs recorded with Leucaena, comparing uninfected to infected kids, reveals a lower availability of nutrients. This result is in agreement with lowest digestible DM and digestible $\mathrm{CP}$ intake being recorded with infected kids fed L. leucocephala.

To our knowledge, the literature does not mention in vivo trials demonstrating the nutraceutical properties of Leucaena leaves, although anthelmintic properties of the seeds have been shown. However, the results concerning health indicators show an expected anthelmintic activity of this forage, probably due to the presence of the CTs. Indeed, the anthelmintic properties of CTs have been widely documented in the literature [8, 18-20].

Feeding pelleted L. leucocephala was effective in reducing GIN infection in kids, although drying and heating have a depressive effect on the CT content of forages. Several authors $[9,21,22]$ have reported similar results with pellets of Espedeza cuneate. In our study, the method used to produce the pellets was sun drying followed by heating during pelleting at a temperature below $70{ }^{\circ} \mathrm{C}$ for less than $5 \mathrm{~min}$. We hypothesise that this method did not destroy the anthelmintic properties of the CTs. This result is particularly interesting, since the CTs of Leucaena would be more sensitive to drying and heating than those of other species [23].
The anthelmintic activity was only found with high levels of incorporation of $L$. leucocephala in the diet. Our study indicates that the anthelmintic effect appears only with the highest levels (60\% DMI) of L. leucocephala, and thus CTs (4.5\% DMI) in the diet. This result is similar to those presented in the literature [19], indicating that approximately 30 to $40 \mathrm{~g} \mathrm{CT} / \mathrm{kg}$ DM is useful for anthelmintic activity. It is likely that this range of values varies according to the characteristics of the CTs. The anthelmintic activity of CTs is more attributable to a reduction in the fertility of female worms rather than to the survival rate of larvae [24]. This experiment demonstrates the effects of tannins at the different stages of the parasite cycle, as reported by Hoste [7]. The reduction in the number of eggs in female worms together with a reduction in their length with the Leucaena diet could illustrate a decrease in their fecundity. The reduction of daily eggs excreted with Leucaena seems to validate this hypothesis because the number of female worms is similar between diets. The increase in the proportion of immature female worms with Leucaena relative to the other treatments might also explain the low female fertility. In addition, the reduction in the Faecal eggs development into larvae in relation to CTs demonstrated in this study is consistent with previous results [7]. This could be due to a direct or indirect effect on egg physiology. A reduced establishment of infective third-stage larvae with tannins is also reported by Brunet [25].

\section{Conclusions}

L. leucocephala pellets have the two main properties of a nutraceutical: feed and anthelmintic. As a feed, L. leucocephala is high in protein, enabling Creole goats to reach approximately $80 \%$ of their growth potential. As an anthelmintic, L. leucocephala reduces the faecal eggs development of eggs into larvae, therefore limiting environmental contamination and reducing the fertility of female worms.

\section{Methods}

The experimental design was designed to evaluate the anthelmintic activity of increasing doses of L. leucocephala pellets on Haemonchus contortus. To avoid possible bias, the assessors were blinded to any stages of the methodological process.

\section{Feed}

The diets consisted of hay, alfalfa pellets, Leucaena leaf pellets, and soybean meal. The composition of the ingredients is shown in Table 5. The hay used was mainly composed of 60-day-old Dichanthium spp. from a fertilised and irrigated natural savannah grass. L. leucocephala was a mixture from collections on 9-12-monthold fallow, unfertilised farmlands. The soils were 
Table 5 Chemical composition of the ingredients of the diets

\begin{tabular}{lllllll}
\hline \multicolumn{7}{l}{ Chemical compound (g/100 g) } \\
\hline Ingredients & OM & NDF & ADF & ADL & CP & CT \\
Dichanthium spp. hay & 93.4 & 76.1 & 39.3 & 5.0 & 8.3 & . \\
Alfalfa pellet & 89.6 & 43.0 & 30.6 & 7.8 & 15.8 & . \\
L. leucocephala pellet & 91.3 & 38.7 & 25.2 & 16.7 & 26.6 & 7.5 \\
Soya meal & 93.6 & 12.2 & 7.3 & 0.7 & 45.3 &. \\
\hline
\end{tabular}

OM Organic Matter, NDF Neutral detergent fibre, ADF Acid detergent fibre, $A D L$ Acid detergent lignin, $C P$ Crude protein, $C T$ Total condensed tannins

diversified: deep ferralitic soils, allophane and halloysite soils, and vertisols. The young stems and leaves, less than 6 months old, were harvested and then sun dried for 2 days. The leaves with petioles were separated from the stem, ground (through a 3-mm screen), and granulated with a GR150E system (Oliotechnology, Burgun, Wissembourg, France). The average size of the pellets was $12 \mathrm{~mm}$ long by $3 \mathrm{~mm}$ in diameter. Alfalfa pellets were sourced commercially.

The four diets were formulated to be iso-nitrogenous. Due to the higher nitrogen content of Leucaena than alfalfa, soybean meal was used to balance the nitrogen in the diet. The diet compositions (\% raw material) were:

Diet A, Hay ad libitum +300 g (62\% alfalfa $+38 \%$ soybean).

Diet 25 L, Hay ad libitum +300 g (47\% alfalfa $+25 \%$ Leucaena $+28 \%$ soybean).

Diet 50 L, Hay ad libitum +300 g (30\% alfalfa $+50 \%$ Leucaena $+20 \%$ soybean).

Diet L, Hay ad libitum + 300 g Leucaena.

The animals were fed every morning at $8 \mathrm{a} . \mathrm{m}$. with the distribution of pellets and then hay 30 min later. Water was available, ad libitum, with automatic distributors.

\section{Animals and experimental design}

Forty-six goat male kids (4 months old, on average $11 \pm$ $1.7 \mathrm{~kg}$ at the beginning of the experiment), coming from the farm of the INRA experimental unit (PTEA, Plateforme Tropicale d'Expérimentation sur l'Animal) were used during the 3-month trial. Animal husbandry complies with French legislation. The protocol (APAF IS\#5527-2016050608133139v2) has been validated by the Ministry of National Education, Higher Education and Research under the advice of the Ethics Committee for Animal Experiments $\mathrm{N}^{\circ} 069$. The planning of the experiment was: 2 weeks of diet adaptation, 4 weeks of measurements before artificial infection of the required number of the kids, 6 weeks of post-infection measurements, including slaughter of 20 kids 4 weeks postinfection. To ensure the animals started the experiment worm-free, the kids were all previously orally administered praziquantel (Cestocure ${ }^{\bullet}$ Bayer) $(3.75 \mathrm{mg} / \mathrm{kg}$ body weight (BW)) and ivermectin (Oramec, Merial, Lyon, France), $0.3 \mathrm{mg} / \mathrm{kg}$ BW. The FEC levels were checked after treatment. The kids were experimentally infected, 6 weeks after the beginning of the experiment, with a single oral dose of $500 \mathrm{H}$. contortus third-stage infective larvae (L3)/kg live weight. This dose allows to reach a level of infection, measured by the concentration of eggs in the faeces, similar to a high infection under the conditions of grazing farming. The kids were allocated to six lots depending on the diet fed and the parasitic status of the animals (infected vs. uninfected). The six lots were:

Lot UA, five uninfected kids fed Diet A.

Lot UL, five uninfected kids fed Diet L.

Lot IA, nine kids infected with Haemonchus contortus and fed Diet A.

Lot IL25, nine kids infected with Haemonchus contortus and fed Diet L25.

Lot IL50, nine kids infected with Haemonchus contortus and fed Diet L50.

Lot IL, nine kids infected with Haemonchus contortus and fed Diet L.

The kids were assigned at random and indifferent to the control or experimental lots which were balanced on the basis of the weight of the kids and their growth between 30 and 90 days after birth. We have excluded extreme kids, too heavy or too light, from an initial population of sixty kids. The size of the lots was based on current practices in this type of experimentation and reported in the literature [15]. Some of the kids were placed in individual boxes $(1.5 \times 1.5 \mathrm{~m}$ size $)$ on the ground (4/lot), except for the uninfected control lot. The other infected kids (5/lot) and the uninfected kids (5/lot) were in metabolic cages $(1.5 \times 0.5 \mathrm{~m}$ size $)$ for the collection of urine (5 consecutive days every 15 days). All animals were equipped with faecal bags for 5 consecutive days every 15 days.

\section{Measurements and calculations}

All measurements were carried out individually on the kids. These measures cover both indicators of kids' responses to feed and indicators of their health status. The kids were individually weighed at the beginning of the experiment and then fortnightly until the end of the trial (90 days). Daily live weight gain (LWG, g/day) was estimated fortnightly from final minus initial body weight. Feed intake was recorded individually for each kid, from Monday to Friday throughout the experiment, by difference between amounts of feeds offered and refused. The dry matter intake of each ingredient, total intake and its components (organic matter (OM), neutral detergent fibre (NDF), acid detergent fibre (ADF), and crude protein $(\mathrm{CP})$ ) were expressed on a daily and metabolic weight basis. The feed efficiency ( $\mathrm{FE}=$ daily live weight gain/daily feed intake) was estimated for each treatment. 
The kids were fitted with faecal bags in order to collect the total daily faeces to study the digestibility of the diet. Samples representing $10 \%$ of the daily excretion of faeces and urine were taken from each kid to have a representative sample for chemical analysis. Daily samples of faeces were used for DM determination and for chemical analyses. Four measurement periods of total tract digestibility (each one lasting 5 days) were carried out during the experiment: two before and two after the artificial infection. The total tract digestibility was estimated as: (feed intake - faeces excreted)/feed intake.

The blood was sampled weekly from each kid by the jugular vein puncture method using EDTA-coated tubes (Becton Dickinson, Plymouth, UK). A method described by Dawkins [26] was used to estimate the number of circulating eosinophils. Malassez cell counter were used to count the eosinophils. Capillary microhaematocrits (centrifuged for $5 \mathrm{~min}$ at $12,000 \mathrm{rpm}$ ) were used to estimate the Packed Cell Volume (PCV).

Synchronously with blood sampling, faeces were collected to determine the FEC using the McMaster method based on the microscopic egg counting of an aliquot of suspension from a known volume of faeces. Ten grams of faeces have been previously dissolved in $50 \mathrm{ml}$ of a saturated solution of sodium chloride which causes the eggs to float. Three weeks after the artificial infection, faecal samples from each kid were cultured for 8 days at room temperature following the protocol described by Roberts and O'Sullivan [27] to determine the development of faecal eggs. Three samples per day and per kid were used. Five replicates were performed per kid and per week.

Twenty-nine days after the infection, five kids from each infected lot were slaughtered for worm recovery and numeration. The kids were humanely slaughtered using a captive bolt pistol which hits them on the head producing immediate unconsciousness following by exsanguination. The abomasum was isolated from the animal less than $10 \mathrm{~min}$ after slaughter and processed immediately. It was cut open over a tray to catch the contents, which were then placed into a flask. The abomasum wall was washed thoroughly under a stream of tap water and the washings were placed into another flask (washing 1). The abomasal mucosa (after being washed) was retained in a third flask for further processing. The abomasal mucosa was immersed in warm tap water for $4-5 \mathrm{~h}\left(37^{\circ} \mathrm{C}\right)$ to recover inhibited or noninhibited larvae and the remaining juvenile and adult worms (washing 2). Up to $2 \mathrm{~L}$ of water were added to the contents during each washing. The contents, mixed with water, were sieved through a $125 \mathrm{~mm}$ wire-mesh screen and the washings sieved through a $32 \mathrm{~mm}$ wiremesh screen. Each subsample (corresponding to the contents and washings 1 and 2 for each kid) was mixed manually and three aliquots $(100 \mathrm{~mL})$ of each subsample were taken to ensure homogeneous sampling. One $100 \mathrm{~mL}$ subsample (i.e., approximately $10 \%$ of the total washing volume) was taken per animal. Formalin preservative (35\% ethanol, $2.5 \%$ formol, qsp $1000 \mathrm{~mL}$ distilled water) was added to the subsamples $(5 \%, v / v)$, which were stored at $4{ }^{\circ} \mathrm{C}$ until counting. The worms were identified and counted in each subsample under a binocular magnifier glass (magnification 6.3-50x), separating the males from the females, and the total worm count was determined. The lengths of 10 female worms per kid were measured using a calliper. In utero egg counts were performed on these 10 female worms as described by Kloosterman et al. [28]. The fertility of female worms was estimated by calculating the ratio between the daily excretion of eggs (averaged over the 5 days prior to slaughter) and the number of worms counted in the abomasum.

The liver, kidney, and abomasum wall were observed to identify any necrotic damage and gastritis as indicators of the eventual toxicity of the diet.

\section{Laboratory analysis}

The DM content of diet ingredients, refusals, and faeces was determined by drying at $60{ }^{\circ} \mathrm{C}$ in a forced draught oven to constant weight. These samples were used for laboratory chemical analysis after grinding through a 1mm screen (Reich hammer mill, Haan, Germany). The organic matter $(\mathrm{OM})$ and $\mathrm{N}$ analyses were conducted according to AOAC [29] methods 923.3 and 992.15, respectively, by ashing at $550{ }^{\circ} \mathrm{C}$ for $6 \mathrm{~h}$ for $\mathrm{OM}$ and using the Dumas method for N. The Crude Protein (CP) was estimated by multiplying $\mathrm{N}$ by 6.25 . Analyses of the $\mathrm{N}$ content of fresh urine samples were performed using also the Dumas method. The cell wall components (NDF, ADF and acid detergent lignin (ADL)) in the diets and faeces were determined using a sequential procedure ([30], AOAC methods 200.04 and 973.18, respectively, for NDF and ADF + ADL, 15). Condensed tannins were extracted in an ultrasonic bath with a $70 \%(\mathrm{vol} / \mathrm{vol})$ aqueous acetone solution [31] and isolated with Sephadex LH-20 (Sigma-Aldrich, St Louis, MO, USA). The $\mathrm{CT}$ content was determined using the vanillin- $\mathrm{H}_{2} \mathrm{SO}_{4}$ method described by Laurent [32]. A 70\% (vol/vol) $\mathrm{H}_{2} \mathrm{SO}_{4}$ solution containing $1 \%$ vanillin (wt/vol) was added to the methanolic extract of the plant and the absorbance measured at $500 \mathrm{~nm}$. The concentrations were determined using standards of tannin extracts from Leucaena.

\section{Statistical analyses}

Intake, total tract digestibility, ADG, eosinophil numbers, PCV, and FEC were analysed in a randomised design using the mixed procedure of SAS [33]. Only the 
raw means of PCVs and FECs are reported in the tables. However, the PCVs and FECs were log-transformed (log $(\mathrm{PCV}+1), \log (\mathrm{FEC}+1))$ before analysis. The analyses were performed taking into account treatment $(n=07)$, the week relative to the date of the artificial infection $(\mathrm{n}=$ $11)$ and the random effect of the animal $(n=55)$. Differences between means were tested using the pdiff option. Significance was declared at probability levels of $\leq 5 \%$.

The model was:

$$
Y_{i j k}=\mu+\operatorname{Tr} i+T_{j}+A_{k}+e_{i j k}
$$

where $\mathrm{Y}_{i j}$ is the explained variable, $\mu$ is the mean, $\operatorname{Tr}_{i}$ is the treatment fixed effect $(\mathrm{I}=1-7), T_{j}$ is the week relative to the date of the artificial infection $(I=1-11), A_{k}$ is the random effect associated with the animal $(k=1-55)$, and $\mathrm{e}_{i j k}$ is the residual term.

The development of faecal eggs and the abomasum worm count were analysed in a randomised design using the General Linear Model procedure of SAS taking into account diet as a fixed effect. The pdiff option was used to test the differences between means.

\section{Abbreviations \\ ADF: Acid detergent fibre; ADG: Average daily growth; ADL: Acid detergent lignin; NCR: Conventional resources rich in protein; CT: Condensed tannins; CP: Crude protein; DM: Dry matter; ED: Effective degradability; FEC: Faecal egg counts; GIN: Gastrointestinal parasitic nematodes; IA: Kids infected with the susceptible strain and fed Diet 1; IL25: Kids infected with the susceptible strain and fed Diet 2; IL50: Kids infected with the susceptible strain and fed Diet 3; IL: Kids infected with the susceptible strain and fed Diet 4; NDF: Neutral detergent fibre; PCV: Blood packed cell volume; Ttd: Total tract digestion; UA: Uninfected kids fed Diet 1; UL: Uninfected kids fed Diet 4}

\section{Acknowledgements}

Some preliminary results of this study were reported in abstract in the 10th International Symposium on the Nutrition of Herbivores.

The authors thank Tatiana Silou Etienne, Christan Deloumeau, Xavier Godard, Claude Barbier, and Pierre Justin Dumoulin for their technical assistance.

\section{Authors' contributions}

$C M M, J C B$ and $H A$ are the researchers involved in writing the experimental protocol, data analysis and article writing. SC, DJB and NM are Master's and PhD students who participated in this work. FP1 and FP2 are the main animal experiment technicians for this work. BC and LP are the main laboratory analysis technicians for this work. All authors have read and approved the manuscript.

\section{Funding}

This study was completed with the financial support (laboratory analysis, cost of animals and livestock inputs, etc...) of the INRA metaprogramme GISA StreP, of the Region Guadeloupe, and European funding: FEDER (AgroEcoDiv project) and FEADER (RITA TRANS'BOV). The funding bodies did not participate in the design of the study and collection, analysis, and interpretation of data and in writing the manuscript.

\section{Ethics approval and consent to participate}

The study was conducted in an INRA experimental unit in Guadeloupe that has an Accreditation to Experiment ( $\left.\mathrm{n}^{\circ} \mathrm{A} 971802\right)$. This involves staff being trained in experimentation and animal welfare. All samples used in this study were collected from Creole goat kids. The animals were treated in accordance with the guidelines and regulations for animal experimentation of the French Ministry of Agriculture. The project (APAFIS\#55272016050608133139v2) was approved by the by the Ministry of National Education, Higher Education and Research under the advice of the Ethics
Committee for Animal Experiments No069 (Comité d'Ethique en Matière d'Expérimentation Animale des Antilles et de la Guyane (CEMEA-AG)). It is a joint committee of INRA (French National Institute for Agricultural Research), CIRAD (The French agricultural research and international cooperation organization) and UA (University of Antilles).

\section{Consent for publication}

Not applicable.

\section{Availability of data and materials}

Data supporting the conclusions of this article are included within the article. Raw data are available upon request from the corresponding author.

\section{Competing interests}

The authors declare that they have no competing interests.

\section{Author details}

'INRAE, UR143, Unité de Recherches Zootechniques, French West Indies, 97170 Petit-Bourg, Guadeloupe. ${ }^{2}$ INRA UE1284, Plateforme Tropicale d'Expérimentation sur l'Animal, French West Indies, 97170 Petit-Bourg, Guadeloupe.

Received: 30 September 2019 Accepted: 13 July 2020

Published online: 10 August 2020

\section{References}

1. Charlier J, Thamsborg SM, Bartley D, Skuce PJ, Kenyon F, Geurden T, Hoste H, Williams AR, Sotirak S, Höglund J, Chartier C, Geldhof P, van Dijk J, Rinaldi L, Morgan ER, von Samson-Himmelstjerna G, Vercruysse J, Claerebout E. Mind the gaps in research on the control of gastrointestinal nematodes of farmed ruminants and pigs. Transbound Emerg Dis. 2018;65(1):217-34.9.

2. Jackson F, Coop RL. The development of anthelmintic resistance in sheep nematodes. Parasitol. 2000;120:95-107.

3. Wolstenholme AJ, Fairweather I, Prichard R, Von Samson-Himmelstjerna G, Sangster NC. Drug resistance in veterinary helminths. Trends Parasitol. 2004; 20:469-76.

4. Jabbar A, Iqbal Z, Kerboeuf D, Muhammad G, Khan MN, Afaq M. Anthelmintic resistance: the state of play revisited. Life Sci J. 2006;79: 2413-31.

5. Mahieu M. 2014. Gestion du parasitisme gastro-intestinal des petits ruminants en zone tropicale humide. PHD thesis, University of Lorraine, France. http://docnum.univ-lorraine.fr/public/DDOC_T_2014_0230_ MAHIEU.pdf.

6. Torres-Acosta JFJ, Hoste H. Alternative or improved methods to limit gastrointestinal parasitism in grazing sheep and goats. Small Rumin Res. 2008;77: 159-73.

7. Hoste H, Torres-Acosta JFJ, Sandoval-Castro CA, Mueller-Harvey I, Sotiraki S, Louvandini H, Thamsborgg SM, Terrill TH. Tannin containing legumes as a model for nutraceuticals against digestive parasites in livestock. Vet Parasitol. 2015;212:5-17.

8. Mueller-Harvey I, Bee G, Dohme-Meier F, Hoste H, Karonen M, Kölliker R, Lüscher A, Niderkorn V, Pellikaan WF, Salminen JP, Skøt L, Smith LMJ, Thamsborg SM, Totterdell P, Wilkinson I, Williams AR, Azuhnwi BN, Baert N,Anja Grosse Brinkhaus, Giuseppe Copani, Olivier Desrues, Chris Drake, Marica Engström, Fryganas C, Girard M, Huyen NT, Kempf K, Malisch C, Mora-Ortiz M, Quijada J, Ramsay A, Ropiak HM, Waghorn GC.Benefits of Condensed Tannins in Forage Legumes Fed to Ruminants: Importance of Structure, Concentration, and Diet Composition. Crop Sci. 2019; 59:1-25.

9. Terrill TH, Mosjidis JA, Moore DA, Shaik SA, Miller JE, Burke JM, Muir JP, Wolfe R. Effect of pelleting on efficacy of sericea lespedeza hay as a natural dewormer in goats. Vet Parasitol. 2007;146:117-22.

10. Gaudin E, Simon M, Quijada J, Schelcher F, Sutrac JF, Lespine A, Hoste H. Efficacy of sainfoin (Onobrychis viciifolia) pellets against multi resistant Haemonchus contortus and interaction with oral ivermectin: Implications for on-farm control. Vet Parasitol. 2016;227:122-9.

11. Ceriac S, Magdeleine Marie C, Periacarpin F, Archimède H. Nutritional management of health and welfare Evaluation of nutraceutical properties of Leucaena leucocephala leaves pellets fed to kids. Adv Animal Biosci. 2018;175.

12. Archimède $H$, Rira $M$, Barde $D J$, Labirin F, Marie-Magdeleine $C$, Calif $B$, Periacarpin F, Fleury J, Rochette Y, Morgavi DP, Doreau M. Potential of 
tannin-rich plants, Leucaena leucocephala, Glyricidia sepium and Manihot esculenta, to reduce enteric methane emissions in sheep. J Anim Physiol Anim Nutr. 2016;100:1149-58.

13. Coop RL, Holmes PH. Nutrition and parasite interaction. Int J Parasitol. 1996; 26:951-62.

14. Kyriazakis I. Is anorexia during infection in animals affected by food composition? Anim Feed Sci Tech. 2010;156:1-9.

15. Ceï W, Salah N, Alexandre G, Bambou JC, Archimède H. Impact of energy and protein on the gastro-intestinal parasitism of small ruminants: a metaanalysis. Livest Sci. 2018;212:34-44.

16. Coop RL, Kyriazakis I. Influence of host nutrition on the development and consequences of nematode parasitism in ruminants. Trends Parasitol. 2001; 17:325-30.

17. Kyriazakis I, Houdijk J. Immunonutrition: nutritional control of parasites. Small Rumin Res. 2006:62:79-82.

18. Nguyen TM, Van Binha D, Ørskov ER. Effect of foliages containing condensed tannins and on gastrointestinal parasites. Anim Feed Sci Tech. 2005;121(1-2):77-87.

19. Hoste H, Jackson F, Athanasiadou S, Thamsborg SM, Hoskin SO. The effects of tannin-rich plants on parasitic nematodes in ruminants. Trends Parasitol. 2006;22(6):253-61.

20. Waghorn G. Beneficial and detrimental effects of dietary condensed tannins for sustainable sheep and goat production - progress and challenges. Anim Feed Sci Tech. 2008;147:116-39.

21. Burke JM, Whitley NC, Pollard DA, Miller JE, Terrill TH, Moulton KE, Mosjidis JA. Dose titration of sericea lespedeza leaf meal on Haemonchus contortus infection in lamb and kids. Vet Parasitol. 2011;181:345-9.

22. Gujja S, Terrill TH, Mosjidis JA, Miller JE, Mechineni A, Kommuru DS, Shaik SA, Lambert BD, Cherry NM, Burke JM. Effect of supplemental sericea lespedeza leaf meal pellets on gastrointestinal nematode infection in grazing goats. Vet Parasitol. 2013;191:51-8

23. Hove L, Ndlovu LR, Sibanda S. The effects of drying temperature on chemical composition and nutritive value of some tropical fodder shrubs. Agrofor Syst. 2003:59:231-24.

24. Min BR, Pomroy WE, Hart SP, Sahlu T. The effect of short-term consumption of a forage containing condensed tannins on gastrointestinal nematode parasite infections in grazing wether goats. Small Rumin Res. 2004;51:279-83.

25. Brunet S, Martinez-Ortiz De Montellano C, Torres-Acosta JFJ, Sandoval-Castro CA, Aguilar-Caballero AJ, Capetillo-Leal CM, Hoste H. Effect of the consumption of Lysiloma latisilliquum on the larval establishment of parasitic nematodes in goats. Vet Parasitol. 2008;157:81-8.

26. Dawkins HJS, Windon RG, Eagleson GK. Eosinophil responses in sheep selected for high and low responsiveness to Trichostrongylus colubriformis. Int J Parasitol. 1989;19:199-205.

27. Robertson FHS, O'Sullivan JP. Methods for egg counts and larval cultures for strongyles infesting the gastrointestinal tract of cattle. Aust J Agric Res. 1952;1:99.

28. Kloosterman A, Albers GAA, Van den Brink R. Genetic variation among calves in resistance to nematode parasites. Vet Parasitol. 1978:4:353-68.

29. AOAC. Official methods for analysis. Gaithersburg: Association of Official Analysis Chemists; 1990.

30. AOAC. Official methods for analysis. Gaithersburg: Association of Official Analysis Chemists; 2006.

31. Giner-Chavez BI, Van Soest PJ, Robertson JB, Lascano C, Reed JD, Pell AN. A method for isolating condensed tannins from crude plant extracts with trivalent ytterbium. J Sci Food Agric. 1997;74:359-68.

32. Laurent $\mathrm{S}$. Etude comparative de différentes méthodes d'extraction et de dosage des tannins chez quelques ptéridophytes. (In French). Arch Int Physiol Biochim. 1975;83:735-52.

33. SAS. SAS language guide for personal computers, version 8.1. Cary: SAS Institute Inc:; 2000.

\section{Publisher's Note}

Springer Nature remains neutral with regard to jurisdictional claims in published maps and institutional affiliations.

\section{Ready to submit your research? Choose BMC and benefit from:}

- fast, convenient online submission

- thorough peer review by experienced researchers in your field

- rapid publication on acceptance

- support for research data, including large and complex data types

- gold Open Access which fosters wider collaboration and increased citations

- maximum visibility for your research: over $100 \mathrm{M}$ website views per year

At BMC, research is always in progress.

Learn more biomedcentral.com/submissions 